\title{
Private forest landowner's perceptions of forest grazing in Washington state
}

\author{
LINDA H. HARDESTY, JOHN H. LAWRENCE, STEVEN J. GILL, ROGER C. \\ CHAPMAN
}

\begin{abstract}
At the time of research authors were assistant professor and research assistant, Department of Natural Resource Sciences, consultant in Academic Computing Services, and professor, Department of Natural Resource Sciences-all at Washington State University, Pullman, Wash. 99164-6410.
\end{abstract}

\begin{abstract}
Nonindustrial private forest landowners (NIPF) control $21.4 \%$ of Washington's commercial forestland, much of which produces forage. Resident NIPF owners in 3 regions in the state were surveyed to determine their perceptions of forest grazing. Thirty-nine percent of the respondents grazed livestock on forestland they leased or owned, and grazing was perceived by practitioners to contribute significantly to household income. Nonincome-related motivations for owning and managing land were also significant: passing land on to children, keeping it 'natural', conservation, aesthetics, and as a current or future homesite. In western Washington, some forest grazing occurred year round while in eastern Washington it was all seasonal. Cow/calf pairs were the most commonly grazed livestock. The median size forestland parcel owned by forest grazers was 47 ha versus 24 ha for nongrazers. Leasing additional land increased the likelihood of forest grazing. Significant opportunities exist to improve both the condition and productivity of forested ranges. Achieving this requires a clear understanding of landowner's objectives and beliefs. Data are needed to evaluate landowner's perceptions that forest grazing has both economic and amenity benefits.
\end{abstract}

Key Words: woodland grazing, silvopastoral, motivations, survey, NIPF

Washington has the lowest proportion of publicly owned land and the highest proportion of privately owned land of the 11 western states. One-third of Washington is rangeland, half of which is forested. Approximately $21 \%$ (1.5 millions ha) of the state's commercial forestland is owned by nonindustrial private forest landowners (NIPF) (Hanley and Baumgartner 1990). Nonindustrial private forest landowners are those who do not own facilities to process the wood they produce. Recent studies (Wetton 1988, Blatner et al. 1991, Lawrence and Hardesty 1992, Lawrence et al. 1992) suggest that a number of Washington NIPF owners practice forest grazing, and that as much as $65 \%$ of this land is not in acceptable condition (Harris and Chaney 1984). Current lack of knowledge about NIPF's forest grazing practices and motives constrain efforts to assist them in utilizing their resources more effectively.

Grazing in the Pacific Northwest has been documented since the 1840s (Coville 1898, Jardine and Anderson 1919, Pearson 1923, Ingram 1931, Reid 1947, Colwell 1954, Sharrow and Leininger 1983, Harris and Chaney 1984). Early forestland grazing in the Pacific Northwest region followed timber harvest to reduce

This research was supported by the Washington Agricultural Research Center, International Program Development Office and Cooperative Extension, Washington State University.

Manuscript accepted 28 June 1992. unwanted vegetation and the fire hazard this vegetation posed to forest regrowth (Judd 1911, Reid et al. 1938, Byington 1990). As a result, much of the forest land suffered from overgrazing (Hess 1966, Harris and Chaney 1984).

The degradation testifying to this history may have fostered the assumption that livestock grazing and forestry are incompatible (Daniel and Ensminger 1945), a perception that lingers unexamined in many quarters today. If, as some anticipate, public and government concern about fish and wildlife habitat, threatened and endangered species, and water quality results in reduction or elimination of timber harvest and livestock grazing on some public lands in this region, private forest lands may be subjected to increasingly intensive use. There is an urgent need for information on which to base technical recommendations for sound management of these lands in the future.

NIPF owners control over $58 \%$ of all commercial forestland in the US, and consequently, have been studied extensively. Activities such as livestock grazing have been addressed only indirectly, however, and generally from a timber management perspective (Weatherland et al. 1982, Bliss and Martin 1989). Our study examined how Washington NIPF owners perceive forest grazing as a means of meeting their land management objectives.

Objectives of this study were to:

1) determine the extent that forest grazing is used by Washington's NIPF owners,

2) develop insight into NIPF owner's motivations for forest grazing,

3) describe forest grazing practices of NIPF owners in Washington, and

4) determine the information needs of NIPF owners who practice forest grazing.

\section{Methodology}

\section{Sample Frame}

Using the sample frame of a concurrent study of NIPF agroforestry practices (Lawrence and Hardesty 1992, Lawrence et al. 1992), our survey was confined to 3 areas, each consisting of 4 counties where forestry and agriculture were primary land uses (Fig. 1). Geographic location, socioeconomic conditions, and agricultural and horticultural crops produced were considered to insure maximum diversity.

Area 1 , in northcentral and northeastern Washington, is predominantly rural. This area is characterized by 400 to $650 \mathrm{~mm}$ annual precipitation, hot $\left(16-24^{\circ} \mathrm{C}\right)$ dry summers and cold $\left(-6-0^{\circ}\right.$ C) winters. There are 100 frost-free days in the mountains and 140 to 200 frost-free days in the valleys (Franklin and Dyrness 1973, Harris and Chaney 1984). Ranching, forestry, and agriculture (tree fruits, grain, and hay) are the dominant land uses. Forests are dominated by ponderosa pine (Pinus ponderosa Dougl), Douglas 


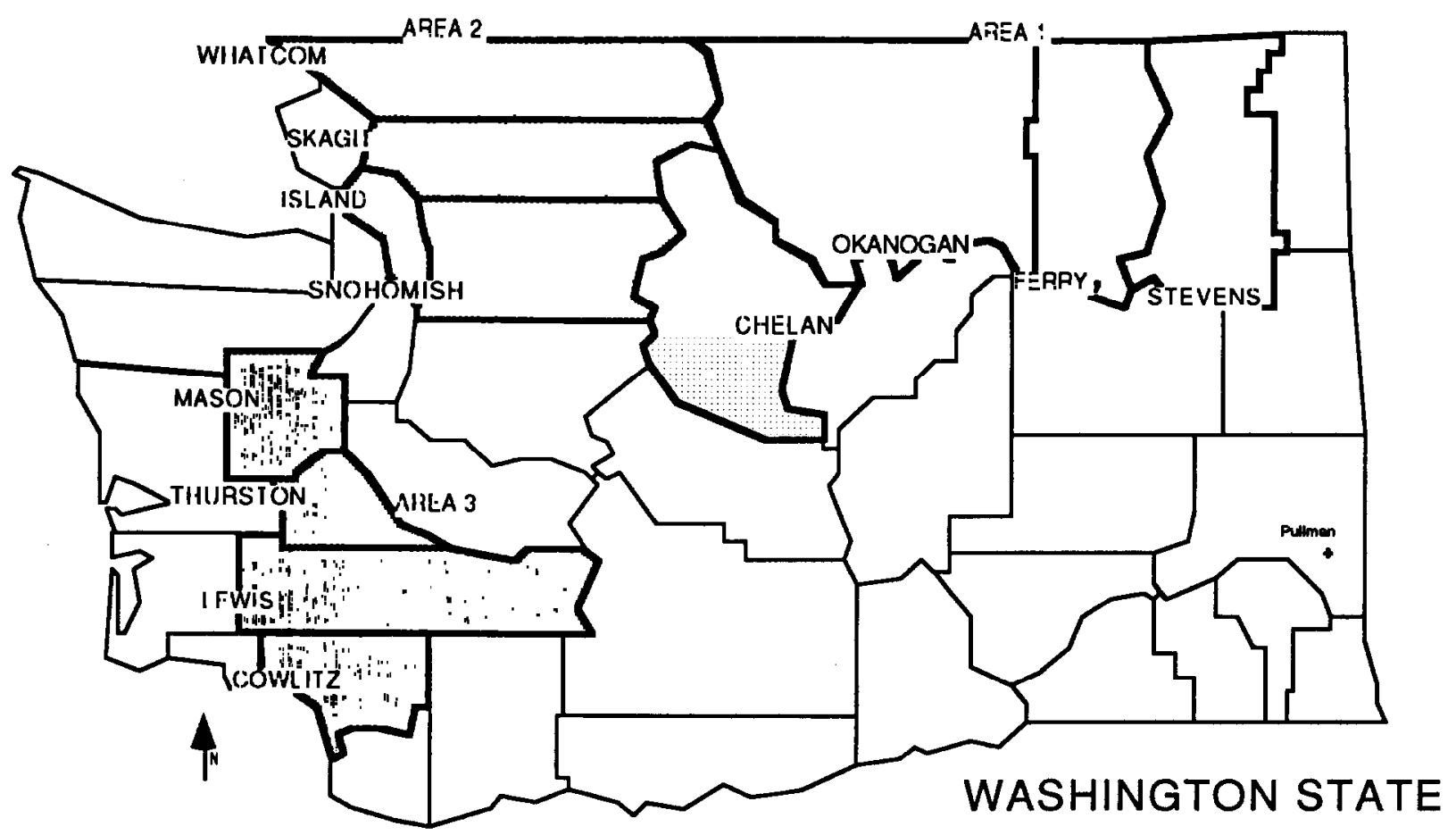

Fig. 1. Areas sampled for Washington State nonindustrial private forest landowner forest grazing practices survey.

fir (Pseudotsuga menziesii (Mirbel) Franco.), lodgepole pine ( Pinus contorta Dougl.), western larch (Larix occidentalis Nutt.), and Engelmann spruce (Picea engelmannii Parry) mixed with true firs (Abies spp. Mill) (Franklin and Dyrness 1973).

Areas 2 and 3 are located in northwest and southwest Washington, respectively. Both are a mix of highly urbanized and rural environments. Important land uses in area 2 include forestry, growing vegetable seeds, potatoes, and bulbs. In area 3 , forestry, mixed farming, and dairy farming are important. The climate of western Washington is relatively mild without the extremes of area 1. Temperatures in the coastal lowlands average from $7^{\circ} \mathrm{C}$ in January to $17^{\circ} \mathrm{C}$ in July. The frost-free season ranges from 200 to 240 days. Average rainfall in areas 2 and 3 ranges from 1,000 to 2,000 mm annually (Harris and Chaney 1984).

The forests of western Washington are some of the world's most productive. Douglas fir forests are the most extensive. Other common forest types include western hemlock (Tsuga heterophylla (Raf.) Sarg.), true firs, and mountain hemlock ( Tsuga mertensiana (Bong.) Carr.) intermixed with western red cedar (Thuja plicata Donn.), red alder (Alnus rubra Bong.), and bigleaf maple (Acer macrophyllum Pursh) (Franklin and Dyrness 1973). Generally, the dense, humid westside forests are not suited for grazing except as transitory range.

\section{Survey Tool}

Data were collected using a mail survey based on Dillman's Total Design Metholody (Dillman 1978). A previously defined population of NIPF landowners randomly selected from county tax records (Blatner et al. 1991) was used to generate mailing lists. Only those forest landowners residing in a county where they owned forest land were surveyed, and we requested that the person most directly responsible for management of the land complete the questionnaire. The survey was pretested and 3 mailings and 3 follow-ups were sent to encourage response. The mailings included a 10-page questionnaire of $\mathbf{4 5}$ questions, cover letter, and pre-paid return envelope. The questionnaire was initially mailed to 680 NIPF owners in August, 1990, and responses were accepted through November, 1990. No survey of nonrespondents was undertaken.

The questionnaire was developed after an earlier, open-ended questionnaire had defined the issues addressed herein (Lawrence and Hardesty 1992). Forest grazing was one of several agroforestry practices included in the study and although it is the only practice reported here, some of the questions addressed a broader range of agroforestry practices. The questionnaire was divided into 5 sections:

1. land: hectares owned and leased from others, location, and tenure;

2. forest grazing practices;

3. reasons for practicing agroforestry, and the potential advantages or disadvantages of agroforestry;

4. reasons for owning land, and the contribution of 12 different products or activities to household income; and

5. socioeconomic characteristics and agroforestry information needs.

Table 1. Percentage distribution of current occupations of forest grazers (FG) and non-forest grazers (NG) within geographic regions.

\begin{tabular}{|c|c|c|c|c|c|c|c|}
\hline \multirow[b]{2}{*}{ Occupation } & \multirow[b]{2}{*}{$\mathbf{N}=$} & \multicolumn{2}{|c|}{ Overall } & \multicolumn{2}{|c|}{ FG } & \multicolumn{2}{|c|}{ NG } \\
\hline & & $\begin{array}{l}\text { FG } \\
113\end{array}$ & $\begin{array}{l}\text { NG } \\
138\end{array}$ & $\begin{array}{c}\text { East } \\
65\end{array}$ & $\begin{array}{c}\text { West } \\
48\end{array}$ & $\begin{array}{c}\text { East } \\
56\end{array}$ & $\begin{array}{c}\text { West } \\
82\end{array}$ \\
\hline \multirow{2}{*}{\multicolumn{2}{|c|}{ rmer }} & - & . & --9 & 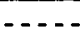 & . & $\ldots$ \\
\hline & & 34.8 & 11.8 & 46.8 & 19.7 & 17.4 & 7.6 \\
\hline \multicolumn{2}{|l|}{ Retired } & 26.1 & 34.2 & 20.8 & 32.8 & 37.0 & \\
\hline \multicolumn{2}{|c|}{ Self-employed other } & 15.9 & 15.5 & 15.6 & 16.4 & 15.9 & 15.2 \\
\hline \multicolumn{2}{|c|}{ Full-time employee } & 11.6 & 22.4 & 7.8 & 16.4 & 23.2 & 21.7 \\
\hline \multicolumn{2}{|c|}{ Part-time employee } & 5.8 & 4.3 & 3.9 & 8.2 & 2.9 & 5.4 \\
\hline \multicolumn{2}{|c|}{ Professional } & 2.9 & 6.8 & 1.3 & 4.9 & 4.3 & 8.7 \\
\hline \multicolumn{2}{|c|}{$\begin{array}{l}\text { Full-time home- } \\
\text { maker }\end{array}$} & 2.2 & 3.1 & 2.6 & 1.6 & 2.9 & 3.3 \\
\hline \multirow{2}{*}{\multicolumn{2}{|c|}{$\begin{array}{l}\text { Unemployed } \\
\text { Full-time student }\end{array}$}} & 0.7 & 0.6 & 1.3 & 0.0 & 1.4 & 0.0 \\
\hline & & 0.0 & 1.2 & 0.0 & 1.4 & 1.1 & \\
\hline & $\overline{100}$ & $\overline{100}$ & $\overline{100}$ & 100 & 100 & 100 \\
\hline
\end{tabular}


Table 2. Total area owned and leased and median parcel sizes controlled by forest grazers (FG) and non-forest grazers (NG), by land type and geographic region.

\begin{tabular}{|c|c|c|c|c|c|c|c|c|c|c|}
\hline \multirow[b]{3}{*}{ Ownership } & & & & & \multicolumn{6}{|c|}{ Median parcel size } \\
\hline & \multicolumn{4}{|c|}{ Total size } & \multicolumn{2}{|c|}{ Overall } & \multicolumn{2}{|c|}{ FG } & \multicolumn{2}{|c|}{ NG } \\
\hline & \multicolumn{2}{|c|}{ FG } & \multicolumn{2}{|c|}{ NG } & FG & NG & East & West & East & West \\
\hline Land owned & 35,896 & (114) & 9,659 & (143) & 100 & 32 & 223 & 64 & 49 & 19 \\
\hline Land leased & 39,374 & $(36)$ & 468 & (11) & 166 & 40 & 239 & 36 & 65 & 40 \\
\hline Forestland owned & 15,138 & & 7,184 & & 47 & 24 & 121 & 41 & 32 & 16 \\
\hline Non-forested owned ${ }^{1}$ & 20,758 & & 2,475 & & - & -- & - & - & - & -- \\
\hline All land (leased \& owned) & 75,270 & & 10,127 & & & & & & & \\
\hline
\end{tabular}

' hectares for non-forestland leased and owned were derived by subtraction.

\section{Statistical Analysis}

Frequency data were obtained for each response. The Chi square equality of means test at $\alpha=0.05$ was used to detect statistically significant differences. When necessary, responses from areas 2 and 3 were combined to meet minimum cell requirements, and referred to collectively as western Washington. Median values were reported for livestock and land ownership data to circumvent the influence of extreme values. Respondents were classified as forest grazers or nonforest grazers. Nonforest grazers may or may not have livestock, but do not use forested lands for grazing. Regional differences (east versus west) in responses were also examined.

\section{Results and Discussion}

Sixty-four percent of the sample population returned useable questionnaires and $39 \%$ of these grazed livestock they owned on forestland they leased or owned. An additional 13\% had practiced forest grazing, but no longer do so due to advancing age or other personal factors. Our results should be qualified with a reminder that only resident NIPF owners were surveyed, hence these results may not apply equally to NIPF owners living more distant from the land they own, and as a result perhaps less able to manage their land.

\section{Demographic Characteristics}

Our respondents differed little from respondents in other state or

Table 3. Percentage distribution of forest grazers (FG) and non-forest grazers (NG) selecting a particular reason for owning land, and selecting particular contributors to total household income, by geographic region.

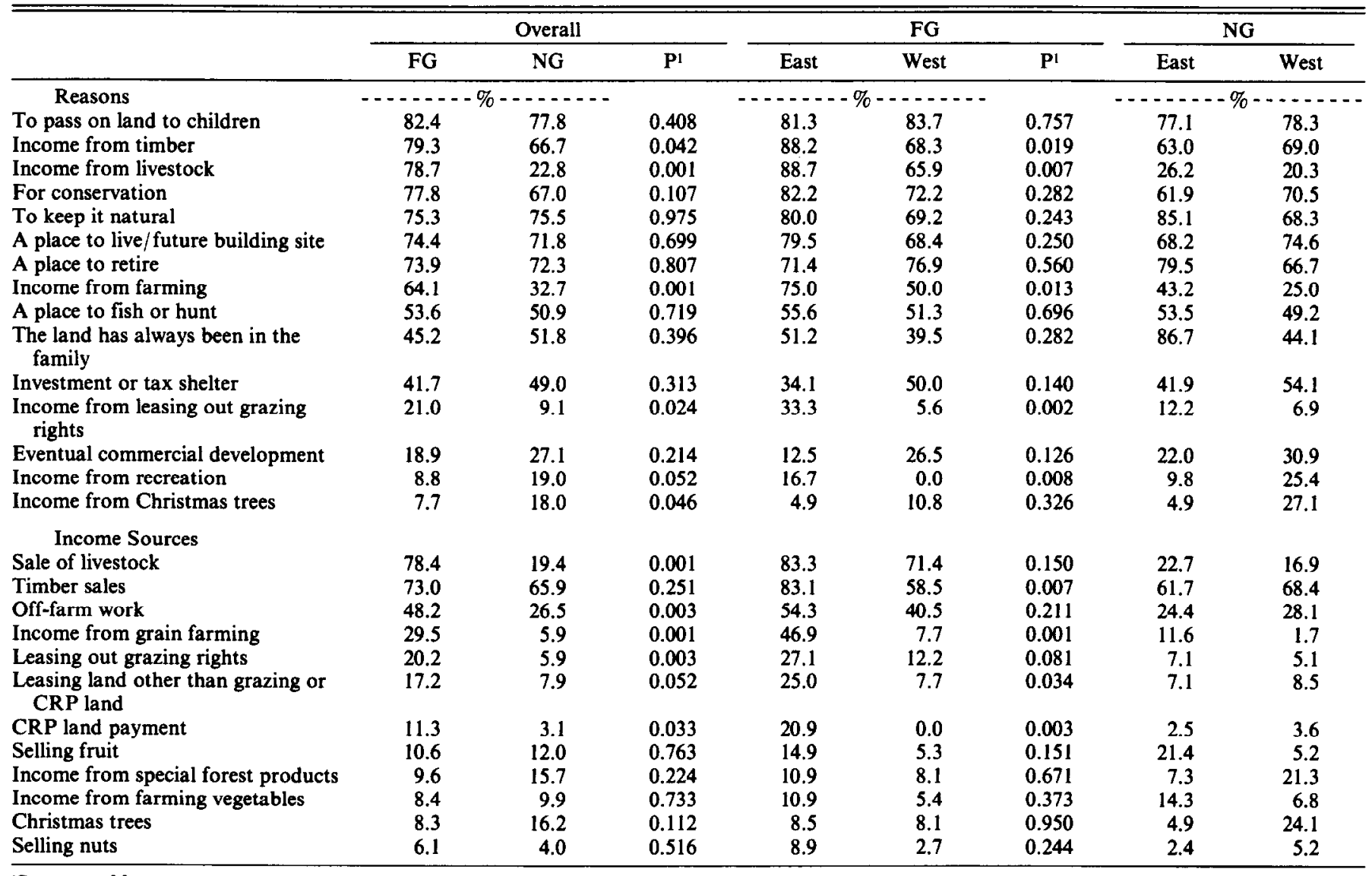

\footnotetext{
'Response of forest grazers and non-grazers overall and response of forest grazers by region. Chi square test for equality of means ( $\propto=0.05$ ).
} 
regional NIPF studies (Baumgartner 1980, Weatherhead et al. 1982, Wetton 1988, Blatner et al. 1991, Force and Lee 1991), permitting us to omit a survey of nonrespondents. Respondents who grazed livestock on forestland were predominantly white $(95.0 \%)$ and male $(89.5 \%)$ with an average age of 58 years. The only notable difference between forest grazers and nonforest grazers was that over twice as large a percentage of nonforest grazers had done graduate study. Average gross annual household income for forest grazers and nonforest grazers were $\$ 53,372$ and $\$ 42,615$, respectively.

Forest grazers most often identified themselves occupationally as a rancher/farmer or retired. Nonforest grazers were most often full time employees or retired. Eastern Washington had a higher proportion of farmer/ranchers and fewer retirees among those who practice forest grazing (Table 1).

Forest grazers owned and leased more land and larger parcels than nonforest grazers (Table 2). Deeded and leased lands made up 53 and $47 \%$, respectively, of all land managed by respondents. Forest grazers control $78.8 \%$ of all deeded land and $98.8 \%$ of the leased acreage managed by survey respondents. Forty-nine percent of the deeded land was forested as was $33 \%$ of the leased land. Dependence on leased land was most evident among eastern Washington forest grazers.

\section{Motivations for Owning Land}

A landowner's reasons for owning land can be expected to influence land management strategies. Our respondents were similar to those in other NIPF studies regarding reasons for owning land (Baumgartner 1980, Weatherhead et al. 1982, Wetton 1988, Blatner et al. 1991, Force and Lee 1991). 'To pass on land to children' was the forest grazer's most frequently stated reason followed by 'income from timber' and 'income from livestock', 'for conservation', and 'to keep it natural' (Table 3). For non-forest grazers, the most frequently cited reasons for owning land were 'to pass on land to children', 'to keep it natural', 'a place to retire', 'a place to live/future building site' and 'for conservation'. Some reasons were cited significantly more often by forest grazers: 'income from timber' ( $p \leq 0.042)$, livestock ( $p \leq 0.001)$, farming ( $p \leq 0.001)$, and leasing out grazing rights $(p \leq 0.024)$. These data suggest that forest grazers' land use is more financially motivated than nonforested grazers', an idea supported by employment and income data. Only 'income from Christmas trees' $(p \leq 0.046)$ was more important to nonforest grazers than to forest grazers. The most frequent reason eastside nongrazers owned land was the 'land has always been in the family'. The importance of nonincome generating motives for owning land should not be underestimated.

Eastside forest grazers cited income from timber $(p \leq 0.019)$, livestock ( $p \leq 0.007)$, farming ( $p \leq 0.013$ ), leasing out grazing rights $(p \leq 0.002)$ and income from recreation $(p \leq 0.008)$ more often than their westside counterparts, perhaps because they control more land and are more likely to be supported by it. Further, farming, livestock, and forestry, as well as off-farm work may all be needed

Table 4. Percentage distribution of forest grazers (FG) and non-forest grazers (NG) indicating choices of potential advantages and disadvantages of agroforestry, as well as reasons others might not consider practicing agroforestry, by geographic region.

\begin{tabular}{|c|c|c|c|c|c|c|c|c|}
\hline & \multicolumn{3}{|c|}{ Overall } & \multicolumn{3}{|c|}{ FG } & \multicolumn{2}{|c|}{ NG } \\
\hline & FG & NG & $\mathbf{P}^{1}$ & East & West & $\mathbf{P}^{\mathbf{1}}$ & East & West \\
\hline Advantages & \multicolumn{3}{|c|}{ 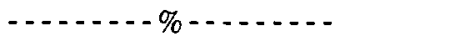 } & \multicolumn{3}{|c|}{$\ldots \ldots$} & \multicolumn{2}{|c|}{$\cdots$} \\
\hline $\begin{array}{l}\text { Integration of conservation and pro- } \\
\text { duction goals }\end{array}$ & 78.6 & 65.9 & 0.080 & 73.7 & 84.4 & 0.278 & 67.6 & 64.7 \\
\hline Aesthetically pleasing & 77.3 & 76.1 & 0.850 & 66.7 & 88.9 & 0.022 & 84.2 & 70.4 \\
\hline Increases land unit income & 76.7 & 69.9 & 0.292 & 75.0 & 78.9 & 0.667 & 73.2 & 67.7 \\
\hline $\begin{array}{l}\text { Diversifies productive and economic } \\
\text { base }\end{array}$ & 75.7 & 59.6 & 0.028 & 70.0 & 82.4 & 0.217 & 59.5 & 59.6 \\
\hline $\begin{array}{l}\text { Improves soil fertility and } \\
\text { productivity }\end{array}$ & 72.0 & 77.4 & 0.420 & 69.0 & 75.8 & 0.520 & 86.8 & 70.9 \\
\hline Water conservation & 71.6 & 69.1 & 0.723 & 75.0 & 66.7 & 0.414 & 84.6 & 58.2 \\
\hline Soil erosion control & 69.5 & 62.9 & 0.352 & 76.1 & 61.1 & 0.144 & 68.3 & 58.9 \\
\hline $\begin{array}{l}\text { Reduced need for pesticides/- } \\
\text { fertilizer/fuel }\end{array}$ & 61.4 & 53.9 & 0.343 & 56.8 & 66.7 & 0.395 & 60.0 & 50.0 \\
\hline Microclimate improvement & 53.7 & 52.8 & 0.909 & 51.4 & 56.3 & 0.693 & 75.0 & 37.7 \\
\hline Establishment cost high & 56.2 & 72.0 & 0.033 & 64.1 & 47.1 & 0.143 & 68.4 & 74.5 \\
\hline $\begin{array}{l}\text { Trees get in the way of farm } \\
\text { equipment }\end{array}$ & 42.3 & 40.7 & 0.844 & 40.5 & 0.760 & 41.2 & 40.4 & \\
\hline Increase in rodent/insect/weed pests & 39.4 & 47.0 & 0.353 & 45.7 & 32.3 & 0.264 & 57.6 & 40.0 \\
\hline Complicated/difficult to manage & 35.9 & 53.5 & 0.033 & 37.1 & 34.5 & 0.825 & 55.9 & 51.9 \\
\hline Livestock compact soil & 31.9 & 39.6 & 0.306 & 11.1 & 52.8 & 0.001 & 40.0 & 39.6 \\
\hline \multicolumn{9}{|l|}{ Reasons. } \\
\hline $\begin{array}{l}\text { Lack of technical assistance/edu- } \\
\text { cation support }\end{array}$ & 62.7 & 63.4 & 0.917 & 63.4 & 61.8 & 0.882 & 73.7 & 56.4 \\
\hline Not practical in commercial situations & 53.4 & 57.1 & 0.634 & 44.7 & 62.9 & 0.121 & 63.9 & 52.7 \\
\hline $\begin{array}{l}\text { No access to livestock or livestock } \\
\text { facilities }\end{array}$ & 49.3 & 59.8 & 0.188 & 50.0 & 4.4 & 0.893 & 57.6 & 61.1 \\
\hline Lack of scientific research & 48.0 & 53.2 & 0.503 & 41.0 & 55.6 & 0.208 & 56.8 & 50.9 \\
\hline $\begin{array}{l}\text { Bias against combining grazing and } \\
\text { forestry }\end{array}$ & 38.7 & 33.3 & 0.484 & 27.5 & 51.4 & 0.034 & 33.3 & 33.3 \\
\hline
\end{tabular}

'Response of forest grazers and non-forest grazers overall and response of forest grazers by region. Chi square test for equality of means ( $\propto=0.05$ ). 
Table 5. Comparison of median and total land area and herd size characteristics of forest grazers who do and do not lease land.

\begin{tabular}{|c|c|c|c|c|c|c|c|}
\hline Leased land & $\begin{array}{l}\text { All land } \\
\text { owned }\end{array}$ & $\begin{array}{l}\text { All land } \\
\text { leased }{ }^{1}\end{array}$ & $\begin{array}{l}\text { Forest land } \\
\text { owned }\end{array}$ & $\begin{array}{c}\text { Forestland } \\
\text { leased }^{2}\end{array}$ & $\begin{array}{c}\text { Forestland } \\
\text { grazed }\end{array}$ & $\begin{array}{c}\text { Head } \\
\text { livestock }\end{array}$ & $\begin{array}{c}\text { Years } \\
\text { practiced }\end{array}$ \\
\hline Yes $(n=37)$ & $\ldots \ldots$ & 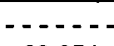 & 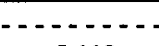 & - (ha).- & $\ldots \ldots$ & $=$ & $\ldots \ldots$ \\
\hline Total & 16,318 & 39,374 & 5,119 & 12,626 & 18,520 & 7,088 & 1,206 \\
\hline Median & 219 & 166 & 51 & 146 & 138 & 65 & 26 \\
\hline \multicolumn{8}{|l|}{ No $(n=77)$} \\
\hline Total & 19,574 & na & 10,000 & na & 9,194 & 3,267 & 1,726 \\
\hline Median & 87 & na & 32 & na & 26 & 20 & 20 \\
\hline
\end{tabular}

Includes all land leased: forestland, pasture, agricultural land, etc.

${ }^{2}$ Includes land leased by one respondent for harvest of special forest products.

Includes all livestock.

to reduce the risk of land based enterprises in the more extreme and variable climate of eastern Washington.

Respondents were asked to indicate important sources of household income (Table 3). Forest grazers most often chose 'sale of livestock', 'timber sales', 'off-farm work', 'income from grain farming', and 'leasing out grazing rights', while nonforest grazers chose 'timber sales', 'off-farm work', 'sale of livestock', 'Christmas trees', and 'income from special forest products'(evergreen boughs and understory plants with culinary or ornamental value). Significantly more forest grazers chose 'sale of livestock' $(p \leq 0.001)$, 'off-farm work', $(p \leq 0.003)$ 'income from grain farming' $(p \leq 0.001)$, 'leasing out grazing rights' ( $p \leq 0.003)$, and 'CRP (Conservation Reserve Program) payments' $(p \leq 0.033)$. These differences are consistent with the reasons forest grazers and nonforest grazers most often cited for owning land, suggesting that forest grazers place greater emphasis on nontimber resources.

Eastern and western Washington forest grazers did not differ in their 3 most frequent income sources: 'sale of livestock', 'timber sales', 'off-farm work'. However, on the eastside 'income from grain farming' replaced 'leasing out grazing rights' as the fourth most frequent choice. For westside forest grazers, 'Christmas trees' and 'income from special forest products' were the fifth most often chosen income sources, compared to 'leasing out grazing rights' in the east. Significantly more eastern forest grazers chose 'timber sales' ( $p \leq 0.007)$, 'income from grain farming' ( $p \leq 0.001)$, 'leasing out grazing rights other than CRP land' $(p \leq 0.034)$ and 'CRP payments' $(p \leq 0.003)$.

Eastern Washington forest grazer's greater reliance on 'income from timber sales' ( $p \leq 0.007)$ may relate to their larger holdings (Table 2). NIPF owners with more than 65 ha of forestland are more likely to actively manage their timber than those with less land (Weatherhead et al. 1982). Timber harvest practices might also be a factor. Westside forests are typically clearcut, an event occurring only rarely during a lifetime, depending on the acreage held. On the eastside, selection and partial cutting (Weatherland et al. 1982) allow landowners to harvest trees more often. Other regional differences; 'income from grain farming', 'leasing out grazing rights other than CRP land' and 'CRP payments', are consistent with region differences in climate and land use.

Motivations for Practicing Agroforestry, Including Forest Grazing

We asked respondents why other landowners such as themselves might not practice agroforestry. Both the forest grazers' and nonforest grazers' most frequent responses were 'lack of technical assistance/educational support', 'not practical in commercial situtions', 'no access to livestock or livestock facilities' and 'lack of scientific research' (Table 4). More western Washington forest grazers indicated 'general bias against combining grazing and forestry' $(p \leq 0.034)$ as a potential obstacle. This is likely due to differing land use histories and forest types.

Based upon their own experiences, forest grazers most often chose as potential advantages of agroforestry: 'integration of con- servation and production goals', 'aesthetically pleasing', 'increases land unit income' and 'diversifies productive and economic base' (Table 4). Differences between forest grazers and nonforest grazers were not significant except that more forest grazers chose 'diversifies productive and economic base' $(p \leq 0.028)$, suggesting a greater concern for economic benefits. The importance of aesthetics to both groups emphasizes that we need to learn what is considered aesthetically pleasing and how these criteria affect, and are affected by, land management practices. Eastern and western Washington forest grazers perceived similar potential advantages of agroforestry, but 'aesthetically pleasing' ( $p \leq 0.022)$ was significantly more important to westside forest grazers.

Economic factors were highlighted in the potential disadvantages of practicing agroforestry perceived by forest grazers: 'financial assistance lacking for unknown practice', 'livestock damage trees or crops', and 'establishment costs high'. Nonforest grazers had similar views, although fewer forest grazers saw 'establishment costs high' as a potential obstacle ( $p \leq 0.033$ ) (Table 4). Establishment costs may be overestimated by nonforest grazers relative to actual costs incurred by forest grazers. 'Complicated or difficult to manage' $(p \leq 0.033)$ was cited twice as often by nonforest grazers. Again, the requirements may be overestimated by the inexperienced. No actual data concerning establishment costs and management inputs are available to clarify these differing perceptions.

Westside forest grazers were more concerned that "livestock damage trees and crops' $(p \leq 0.026)$ and compact soil $(p \leq 0.001)$. The former perception may be a result of regional differences in tree and crop species as well as silvicultural and agricultural practices. Higher precipitation probably explains the concern about soil compaction since east side soils are often wet for extended periods. Both forest grazers and nonforested grazers recognized that forest grazing may be hazardous to other resources, although there are few data quantifying potential damages. Distinctions between proper and improper grazing were not drawn, but should be included in field studies. Because behavior is influenced by beliefs, it is important that the actual hazards and external costs of forest grazing be clarified and shared with land owners.

\section{Forest Grazing Characteristics}

Forest grazing was the most common agroforestry practice used by survey respondents, and the only agroforestry practice employed by $71.9 \%$ of the agroforesters (Lawrence et al. 1992). In eastern Tashington, $46.0 \%$ of all respondents grazed livestock on forestland. Median herd size (cattle only) was 67 . In western Washington, $31.0 \%$ of the respondents grazed livestock on forestland, but the median herd size was only 20 head. Cow/calf pairs constituted $76.0 \%$ of all livestock on forested ranges. One quarter of the forest grazing occurred year round in the counties west of the Cascade mountains. All other forest grazing occurred between early April and early November. Most of Washington's forest ranges are inaccessible for 4 to 6 months annually due to snow or mud.

The most common forest types grazed in eastern Washington 
were Douglas fir, ponderosa pine or Douglas fir mixed with ponderosa pine and western larch. Understory vegetation associated with these forest types includes snowberry (Symphoricarpos albus Gray), oceanspray (Holodiscus discolor (Pursh) Maxim.), bitterbrush (Purshia tridentata (Pursh)), bluebunch wheatgrass (Agropyron spicatum (Pursh) Scribn. \& Smith), Idaho fescue (Festuca idahoensis Elmer), needle-and-thread (Stipa comata Trin. \& Rupr.) and Sandberg bluegrass (Poa sandbergii Vasey) (Reid 1964, Harris and Chaney 1984). Upland forests are important in the summer and autumn when grasses at lower elevations are dry and have little nutritive value (Reid 1947, Reid 1964). Understory forage production varies from $112-4,491 \mathrm{~kg} / \mathrm{ha}$ and is closely associated with the density of the forest overstory, precipitation, soils, and topography (Harris and Chaney 1984).

The most common forest types grazed in western Washington were Douglas fir alone or in association with western red cedar and red alder. The understory offers few preferred forage species except on recent clearcuts: velvet grass (Holcus lanatus L.), trailing blackberry (Rubus ursinus Cham. \& Schlecht.), hairy cat's ear (Hypochaeris radicata L.), pearly everlasting (Anaphalis margaritacea (L.) B. \& H.), and coltsfoot (Petasites frigidus (L.) Fries) provide a significant amount of palatable and nutritious forage (A. Dobkowski personal communication). Forage production on these forest sites ranges from $0-5,614 \mathrm{~kg} / \mathrm{ha}$ (Harris and Chaney 1984), again depending on both environmental and management influences.

Leased lands play an important role in the forest grazing practices of Washington's NIPF owners. Median herd sizes were larger for forest grazers who lease additional land and the median parcel size of deeded forestland was double that of forest grazers who did not lease land (Table 5). Most leased lands are private rather than publicly owned. No doubt there is a minimum acreage (deeded and / or leased) below which forest grazing is not feasible. Grazing permits may contribute to this threshold: $11 \%$ of all respondents held public land grazing permits and $86 \%$ of the permit holders were eastside agroforesters. Having established the importance of grazing on NIPF lands, we should now learn more details of actual forest grazing practices, efficiencies, and problems.

\section{Agroforestry Information Needs}

Both landowners and technical advisors (Lawrence and Hardesty 1992) cited lack of technical assistance, educational support and scientific research as obstacles to implementing agroforestry practices. The type of information respondents would request is another indicator of their concerns and priorities. When asked what, if any, types of agroforestry training or extension information would be useful to them, $46 \%$ of all forest grazers requested information, primarily concerning 'livestock management in agroforestry systems' ( $100 \%$ of forest grazers requesting information), 'management of trees in agroforestry systems' (83\%), 'using trees and shrubs as shelter/forage for livestock' $(65 \%)$ and 'managing forestland for special forest products' $(63 \%)$. Nonforest grazers were most interested in managing for special forest products $(100 \%$ of those requesting information) and managing trees in agroforestry systems (91\%). Interestingly, $43 \%$ of the nonforest grazers were also interested in managing livestock in agroforestry systems, suggesting that some might consider forest grazing if they knew more about it.

Information should be targeted to specific groups of NIPF owners. For example, both forest grazers and nonforest grazers were interested in information about 'management of trees in agroforestry systems', but the 2 groups appear to have different views of the role of trees in agroforestry systems. While differences exist in their perceptions of agroforestry, NIPF owners are sufficiently homogeneous in regards to personal characteristics and motivations to be well served by properly focused educational programs.

\section{Implications and Recommendations}

Forest grazing was practiced by $39 \%$ of the resident NIPF owners responding to our survey. Parcel size was related to the likelihood of forest grazing although it is unclear if more land was obtained in order to produce livestock, or if livestock are used to optimize management of lands already controlled. A larger land area may better support forest grazing by contributing more diverse forage resources and greater opportunities for proper livestock and range resource management. The role of leased lands in forest grazing operations should be clarified, as well as the minimum acreage requirements for successful forest grazing. Cooperative programs or grazing associations may be useful both in accessing sufficient acreage and encouraging proper management.

Assessing range condition on forest lands is complicated by the fact that succession ultimately precludes much forage production, and that the effects of timber management practices and grazing practices are confounded. Harris and Chaney (1984) cite 1981 data from the Soil Conservation Service indicating that $65 \%$ of Washington's State and privately owned grazeable woodlands are producing "less than acceptable" amounts of forage relative to their potential in a given successional state. The state's grazeable woodlands are estimated to be producing only $31 \%$ of the forage they could be producing if all were in satisfactory condition, hence significant opportunities exist to improve both condition and forage production on privately owned forest lands. They recommend thinning and pruning trees on $56 \%$ of the state's grazeable woodlands, and note that few additional practices, other than proper grazing management, and site stabilization following timber harvest, are needed to improve the condition and productivity of these lands. The landowners' willingness to do these improvements is strongly dependent upon their reasons for owning land and their perceptions of various land use practices.

Although forest grazing is perceived by practitioners to contribute significantly to household income, the importance of nonincome related motives for owning and managing land cannot be overemphasized. Focusing exclusively on owners' economic or livestock production objectives could be a serious error given the importance of passing land on to children, keeping it 'natural', conservation, aesthetics, and a current or future homesite. The number of forest grazers reporting these objectives suggests that they are not seen as incompatible with forest grazing. Targeting these objectives should increase the success of programs to improve conditions on privately owned forested ranges.

As in any opinion survey, our results must be qualified: actual behavior is not always consistent with respondent's statements. However, behavior is influenced by beliefs, regardless of the factual basis of those beliefs. We need to verify the accuracy of respondents' perceptions. In some cases, information already exists that may counter some of these perceptions. For example, Halloin (1991) recently reviewed the literature on livestock damage to trees, concluding that little hazard exists with proper managment. Education might reassure NIPF owners in this regard and promote such proper management. In other cases, such as soil compaction, data are not available to determine the potential for forest soil compaction due to grazing. Economic analyses of forest grazing are urgently needed given the prevalence of economic motives, and the fact that economic justification is needed to access funds for improvement of these ranges. The significance of regional differences, both environmental and socio-economic, should be explored in recognition to the range of conditions under which forest grazing is practiced.

This work emphasizes the importance of understanding land 
owner's actual beliefs and practices. For example, an earlier study of land management advisors (Lawrence and Hardesty 1992) did not identify soil compaction as a potential hazard of agroforestry, yet the landowners surveyed frequently expressed this concern. Understanding landowner's values, perceptions, and practices should result in more effective research and extension programs, and ultimately, in better land management.

\section{Literature Cited}

Baumgartner, D.M. 1980. Nonindustrial private forestland owners: Stevens County, Washington. p. 266-268. In: Proc. 1979 Convention Soc. Amer. Forest., Soc. Amer. Forest., Bethesda, Md.

Blatner, K.A., D.M. Baumgartner, and L.R. Quackenbush. 1991. NIPF use of landowner assistance and education programs in Washington State. Western J. App. Forest. 6:90-94.

Bliss, J.C., and A.J. Martin. 1989. Identifying NIPF management motivations with qualitative methods. Forest. Sci. 35:601-622.

Byington, E.K. 1990. Agroforestry in the temperate zone. Chapter 7. In: K.G. MacDicken and N.T. Vergara (eds.). Agroforestry: Classification and Management. John Wiley \& Sons, N.Y.

Colwell, D.E. 1954. Harmonizing forest and range management in the ponderosa pine forests of central Washington. p. 208-210. In: Proc. : Soc. Amer.Forest. Soc. Amer. Forest., Bethesda, Md.

Coville, F.V. 1898. Forest growth and sheep grazing in the Cascade mountains of Oregon. U.S. Div. Forest., Bull. 15.

Daniel, T.W., and M.E. Ensiminger. 1945. Grazing on the cutover land of western Washington. State College of Washington. Agr. Exp. Sta. Population Bull. 179.

Dillman, D.A. 1978. Mail and telephone surveys: The total design method. John Wiley \& Sons, N.Y.

Force, J.E., and H.W. Lee. 1991. Nonindustrial private forest owners in Idaho. Western J. App. Forest. 6:32-36.

Franklin, J.F., and C.T. Dyrness. 1973. Natural vegetation of Oregon and Washington. USDA Forest Serv. Gen. Tech. Rep. PNW-8.

Halloin, L. 1991. Plantation grazing: A feasibility review. Dept. of Natur. Resourc., Forest Land Manage. Div. Olympia, Wash.
Hanley, D.P., and D.M. Baumgartner. 1990. Forest and forest products data: Washington State. Washington State Coop. Ext., Pullman, Wash. EB 1557.

Harris, G.A., and M. Chaney. 1984. Washington State grazing land assessment. Washington State Univ. Coop. Ext. Pullman, Wash.

Hess, J.P. 1966. Management of livestock grazing on private timberland. p. 231-232. In: Proc. Soc. Amer. Forest. Soc. Amer. Forest., Bethesda, Md.

Ingram, D.C. 1931. Vegetative changes and grazing use on Douglas fir cut-over land. J. Agr. Res. 43:387-417.

Jardine, J.T., and M. Anderson. 1919. Range management on the national forests. USDA: Professional Paper. Bull. 790.

Judd, C.S. 1911. Efficacy of goats in clearing brush land in the Northwest. p. 108-112. In: Proc. Soc. Amer. Forest. Soc. Amer. Forest., Bethesda, Md.

Lawrence, J.H., and L.H. Hardesty. 1992. Mapping the territory: Agroforestry awareness among Washington State land managers. Agroforest. Syst. 19:27-36.

Lawrence, J.H., L.H. Hardesty, R.C. Chapman, and S.J. Gill. 1992. Agroforestry practices of Washington State non-industrial private forest land owners. Agroforest. Syst. 19:37-55.

Pearson, G.A. 1923. Natural reproduction of western yellow pine in the Southwest. USDA: Forest Serv. Bull. 1105.

Reid, E.H. 1947. Forest grazing in the Pacific Northwest. p. 296-302. In: Proc. Soc. Amer. Forest. Soc. Amer. Forest., Bethesda, Md.

Reid, E.H. 1964. Forage production in ponderosa pine forests. p. 61-64 In: Proc. Soc. Amer. Forest. Soc. Amer. Forest., Bethesda, Md.

Reid, E.H., L.A. Issac, and G.D. Pickford. 1938. Plant succession on a cutover, burned, and grazed Douglas fir area. Pacific Northwest Forest and Range Exp. Sta. Forest Res. Notes 26.

Sharrow, S.H., and W.C. Leininger. 1983. Sheep as a silvicultural tool in coastal Douglas-fir forests. p. 219-232. In: D.D. Hannaway (cd.). Proceedings foothills for food and forests: Int. Hill Lands Symp. Timber Press, Beaverton, Ore.

Weatherhead, D.J., R.C. Chapman, W.H. Kelso. 1982. Characteristics of NIPF landowners of Spokane County, Washington. Res. Bull. XB 0928, Agr. Res. Center, Washington State Univ., Pullman, Wash.

Wetton, C.E. 1988. A survey of private forest land owners in British Columbia. FRDA Rep. 044. Forest Res. Develop. Agreement, Victoria B.C. 